The CLASSICAL QUARTERLY and CLASSICAL REVIEW are the organs of the Classical

Association. The QUARTERLY is published in January, April, and October (double number); the REVIEW in February, May, July, September, November, and December.

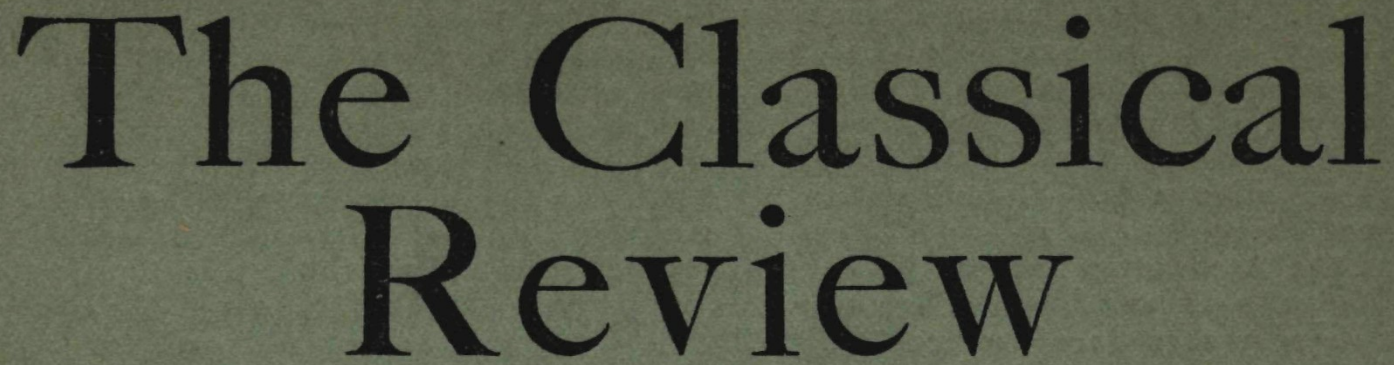

EdrTors $\{$ E. HARRISON, M.A., Trinity College, Cambridge.

(Prof.W. M. CALDER, LL.D., 5, Derby Road, Withington, Manchester.

All correspondence should be addressed to Prof. CALDER. Books for review should be sent to the Publisher.

Board of Management:

Prof. J. F. DOBSON, M.A., Chairman.

Prof. H. WILLIAMSON, M.A., Hon. Treasurer.

L. WHIBLEY, M.A.; Hon. Secretary.

Prof. R. S. CONWAY, | With the Chaiman, TreaProe A. C. GI.AR Litt.D., F.B.A. surer, and Secretary, repre-

Pror. A. C. CLARK, Litt.D.,F.B.A. $\begin{aligned} & \text { senting the Councit } \\ & \text { Classical Association. }\end{aligned}$

E. A. BARBER, M.A., representing the Oxford Philo.

Prof. Dogical Societv. S. ROBERTSON, M.A., representing the Cambridge Philological Society

With the co-operation of Prof. E. K. RAND, Harvard University, and Prof. W. RITCHIE, University of Cape Town.

Vol. XLIII

FEBRUARY, 1929

No. I

\title{
CONTENTS
}

\section{Campanarum Canticum}

Sir John MURRay

JANE ElLEN HARRISON

Zev̀s Túpayyos G. THOMSOY

Notes on Sophocles: Philoctetes. J. C.

Lawson

Plato and Poetical Jústice. J. Tate ..

Two Notes on Herodes. A. D. KnOX ..

Horace: Odes I. 34,35 . L. A. Mackay ..

Two Notes on Livy V. H. Hill ..

BACCHAE 925-6. G. C. RICHARDS ..

Thucydides VI. 34,7 . A. W. Gomme .. I5

REVIEWS :

Some Verse Translations. M. R, GLOVBR.. $A$ Cretan Statuette (Wace). P. J. Dixon ...

Lawyers and Litigants in Ancient Athens

(Bonner). E. W. V. Clifton .. ..

The Athenian Calendar in the Fifth Century

(Meritt). J. K. Fotheringham.. ..

Die Sprache des Redners Hypereides (Pohle).

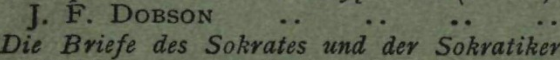

(Köhler). A. E. TAYLOR $\because$.

Hellas the Forerunner, II. (Household). A.

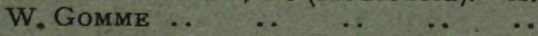

PAGK
I
$I$
$I$
2
3

5
7
8
I0
I2
I5
I5

REviews (continued) :

Hérondas, Mimes (Nairn-Laloy). A. D. $\begin{array}{lllllll}\text { KNOX .. } & \ldots & \ldots & \ldots & \ldots & \ldots\end{array}$ Indogermanische Grammatik (Hirt). J. FRASER $\quad \ldots \quad$.. $\quad$.. $\quad$ * $\ddot{W}$ Macedonian Imperialism (Jouguet). "W. W

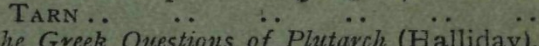
The Greek Questions of Plutarch (Halliday). C. Iuli Caesaris Commentarii, III. (Klotz). H. StEwart
Le Dialecte Laconien (Bourguet). KENZIE $\quad$.. .

Vergilio ed Enea (Terzaghi); Le Réalisme dans les Bucoliques de Virgile (Hubaux).

S. K. Johnson $\ldots$ …

The Roman Legions (Parker). A. $\ddot{M}$. DuFF

The Social and Economic History of the Roman Empire (Rostovtzeff). D. A I KInson ..

Freedmen in the Early Roman Empire (Duff).

M. Cary
The Suasoriae of Seneca the Eider (Edward).

G. B. A. Fletcher
Sénèque, Des Bienfaits, ii. (Préchac).

G. B. A. Fletcher $\quad \ldots \quad \ldots \quad \ldots 3^{8}$

The Invasion of Europe by the Barbarians

(Bury). J. G. C. ANDERSON

The Romanesque Lyric (Allen). S. GaseleE $4^{\circ}$ $\begin{array}{llllll}\text { SHORT REVIEWS } & \ldots & \ldots & \ldots & \ldots & 40\end{array}$

SUMMARIES OF PERIODICALS $\ldots \begin{array}{lllll}\ldots & \ldots & \ldots & 44\end{array}$

$\begin{array}{llllll}\text { BOOKS RECEIVED } & \ldots & \ldots & \ldots & \ldots & 47\end{array}$

LONDON : JOHN MURRAY, ALBEMARLE STREET, W. NEW YORK: G. E. STECHERT \& CO., 31-33, EAST IOTH STREET. 


\section{THE}

\section{L A S S I C A L REVIEW}

Bprres ax

E. HARRISON AND W. M. CALDER

BOARD OF MANAGEMENT:

Prof. J. F. DOBSON, M.A. (Chairman)

Pror. H. WILlIAMSON, M.A. (Hon. Treasurer). $\quad$ L. WHIBLEY, M.A. (Hon. Secretary).

Prof. R. S. CONWAY, Litt.D., F.B.A.; Pror. A. C. ClaRK, Litt.D., F.B.A.

E. A. BARbER, M.A. ; Pror. D. S. ROBERTSON, M.A.

With the co-operation of Prof. E. K. RAND, Harvard University, and Pror. W. RITCHIE, University of Cape Town.

\section{VOLUME XLIII.}

PUBLISHED FOR THE CLASSICAL ASSOCIATION

\section{LONDON}

JOHN MURRAY, ALBEMARLE STREET, W. NEW YORK

G. E. STECHERT \& CO., 3I-33, EAST IOTH STREET 1929 


\section{TABLE OF CONTENTS}

Campanarum Canticum

Sir John Murray

Jane Ellen Harrison

Alexander William Mair

Zè̀s Túparvos. G. Thomson

Notes on Sophocles : Philoctetes. J. C. LAwson

Plato and Poetical Justice. I. TATE.

Two Notes on Herodes. A. D. Krox

Horace : Odes I. 34, 35. L. A. MACKAY

Two Notes on Livy V. H. HILL

Bacchae 925-6. G. C. RICHARDs

Thucydides VI. 34, 7. A. W. GoMxE

\section{Reviews :}

Some Verse Transhations, M. R. Grover, I6; A Cretan Statuette (Wace), P. J. Dixon, I8; Lawyers and Litigants in Ancient Athens (Bonner), E. W. V. Clirion, 19; The Athenian Calendar in the Fifth Century (Meritt), J. K. Fotheringham, 20; Itie Sprache des Redners Hypereides (Pohle), J. F. DoBson, 21 ; Die Briefe des Sokrates und der Sokratiker (Köhler), A. E. TAYLOR, 22; Hellas the Forerunner, II. (Household), A. W. Goume, 23; Hérondas, Mimes
No. 1.

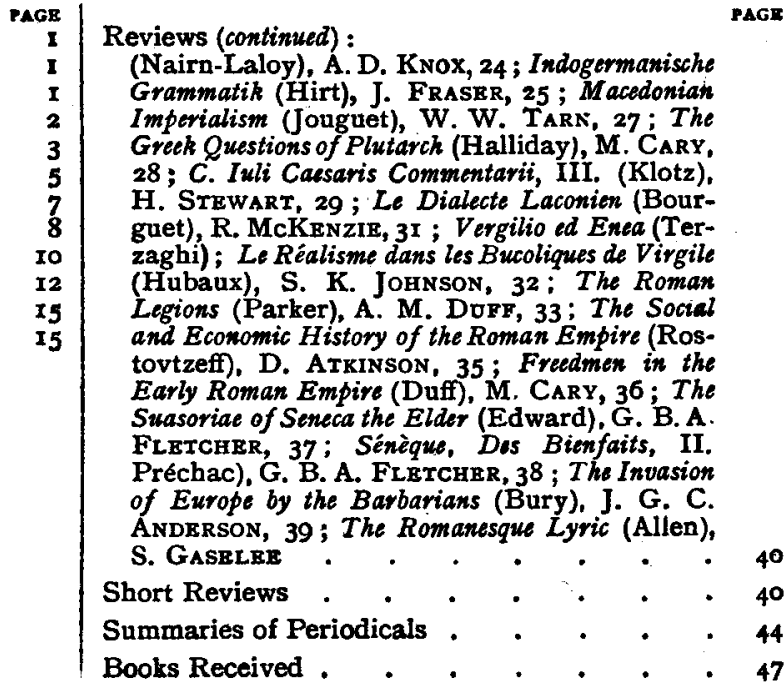

No. 2.

Notes and News

From Horace (Odes I. xxxvii.). J. A. For $\dot{\text { I }}$ A Strange. Law at Sparta. A. D. KNox $\dot{\text { A Greek Inscription from Kurdistan }}$ (C.I.G. 4673). W. W. TARN

Plautus, Bacchides, 635-8. W. Beare

Persius no 'Micher.' J. Tate .

Bdos and tyos. W. RHYs RoBerts .

Epexegetic $\gamma \epsilon$, ]. D. Denniston

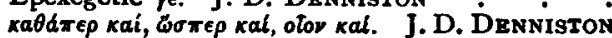

Varro and Orpheus. A. D. Nock

The River of Tears again. H. J Rose '

\section{Reviews :}

Some Compositions, A. D. Nightingale, 62 ; Some Transhations and other Books, E. S. FoRSTER, 63; The Classical Tradition in Poetry (Murray), H. W. GARROD, 64 ; Schallanalytische Versuche (Ipsen-Karg), H. J. Rose, 65 ; A ristophane (Coulon et van Daele), F. W. HALL, 66 ; The Greek $A$ tomists and Epicurus (Bailey), A. E. TAYLOR, 68 ; Strabo, Vols. IV. and V. (Jones), E. W. V. CIIrIoN, $7 \mathrm{I}$; Greek Rhetoric and

Euripides the Irrationalist. E. R, DodDs. .

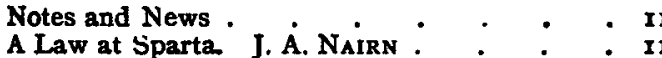

Three Notes on Pindar. W. A. Stone - . II5

Sophocles' Antigone 925, 926. E. C. Woodcock Aristophanes, Clouds, ll. $994-995$. E. C. YoRKE. Four Notes on Greek Particles. J. D. DrN-

The Construction of Verbs of Thinking : $\dot{A}$ Reminder. E. C. Marchant
Reviews (continwed) :

Literary Criticism (Rhys Roberts), ]. D. DENNIsron, 72; Josephus: The Jewisk War (Thackeray), G. W. ButrerWorth, 73; Papyri Graecae Magicae (Preisendanz), H. J. Rosk, 74 ; Plotinus: The Divine Mind (Mackenna); Enréades III., IV.; La Philosophie de Plotin (Bréhier), S. C. NeIL, 75; The Cambridge Ancient History. VII., W.E. HeitLand, 76; Autour des Gracques (Carcopino), M. CARY, 82; Last Words on the Roman Municipalities (Heitland), J. G. C. Anderson, 83; The Commerce between the Roman Empire and India (Warmington), J. O. Tromson, 84; Towards a Text of the Metamorphosis of Ovid (Slater). E. H. AIroN, 85; De Litteris Latinis Commentarii (de Rosa),

Short Reviews . . . . . . . . 89

Cambridge Philological Society . . . . 93

Summaries of Periodicals . . . . 93

Books Received . . . . . . . 96

No. 3.

97 The Historical Significance of the Odes of Horace. E. R. GARNSEY . . . . IO4

No. 4.

I3 An Epigram from Cos. J. D. Brazley aND A. S. F. Gow . . . . . . 120 Plutarch's Quaestiones Graecae, No. 24. $\dot{M}$. P. Nitsson - Catullus, E. H. Misiss and E. HARRISON

IENTOZOL. W. H. D. RösR: : : 125

Bacchae, 925-6. G. C. RichardS . . . I25

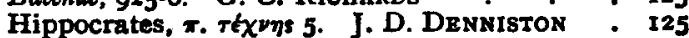
J. WIGHT DUFF 
-A Greek Inscription from Kurdistan': Postcript. W. W. TARN

Hyperborean Offerings. A. D. Nock

Clarlan Apollo. A. D. Nock

Propertius II. 12. A. D. Nock

\section{Reviews:}

Nime Essays (Platt), H. W. GARROD, 127 ; Solon and Croesus (Zimmern), M. N. ToD, 128; $Z y$ goncries (Blegen), M. Bradnholtz, I30; Greeh Vasos in Poland (Beazley). M. Braunholtz, I32: Hésiode (Mazon), T. A. SINCLAIR, I33; Sappho Revocata (Edmonds), C. M. BowrA, I35; Studia Sapphica (Turyn), E. LOBEL, 136; Aristoteles' Gedanke der Philosophie (SchillingWolloy), A. E. TayLoR, 137;A Bibliography of the Poctics of Aristotle (Cooper and Gudeman), H. B. Charlton, 138 ; Greek Physical Education (Forbes), E. N. GARDINER, I39; The

Notes and News .

Alt-Ithaka. A. Sheway

Accents and the Greek Iambic Line. $\dot{F} . R$. DALE A Reference to Lucretius in Cicero, Pra Milone. M. E. HiRsT .

Catullus $66_{51-4 .}{ }^{\circ}$ A. E. Hodsman : : Some Aids to Classical Teaching. W. E. P. Pantin

\section{Reviews :}

Andrew Lang's Work for Homer (Shewan), G. Morray, I69; Die Gesetze des Zaleukos und Chavondas (Mïhl), P. N. URE, 170 ; Some Greek Love Poems (Edmonds), S. GASELER, 172 ; Greek Lyric Metre (Thomson), H. D. F. KITTo, I73 ; Pindar's Odes of Victory (Billson), D.S. RoBERTson, 174; $A$ Handbook of Greek and Roman Architecture (Robertson), W. R. LETHABY, 175 : Die antike Menschbeitsidee (Mühl), R. B. Onians, 176 ; Platonism (Burnet), P. W. Dood, 178; Demostheres gegen Aphobos (Schwahn), M. Cary, I79; On Alexander's Track to the Indus (Stein). W. W. TARN, 180; New Chapters in the History of Greek Literature; Second Series

Notes and News.

Regulations for a Local Sports Meeting. E. Norman Gardiner.

Vergil and the Maze. W. F. J. KNIGHT

Note on Herodotus IV. 108-9. M. CARY

Callimachus on Mimnermus. H. ]. M. MILNE.

The Dithyrambs of Xenocritus. W. M. CALDRR

Tac. Agric. 24 init. W. H. SemplE

The Date of I.B.M. 493. H. Box

Reviews :

God, Man, and Epic Poetry (Routh), R. B. Onians, 215: Daedalus and Thespis (Miller). D. S. RoBerTson 218; A Commentary on Plato's Timaess; Plato, Timaews and Critias, translated (Trylor), J. L. Stocks, 218 ; Etudes sur quelques Partioules de Liaison chex Platon (des Places) I. D. Drensiston, 220 : Epicuri at Epicureorum Sonipta in Herculanensibus Papyris servata (Vo-

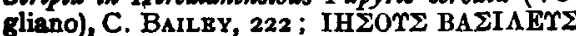

No. 5 .

16I Reviews (continued) :

162 (Powell and Barber), C. M. BowRA, 18I; I65 Anthologie Grecque, Tome I. (Waltz), J. U. PoweLL, 183 ; Die Vorgeschichte der christlichen Taufe (Reitzenstein), H. J. RosR, 184; The Emperor Romanus Lecapenus and his Reign (Runciman), G. Bockler, I85; Plotins Kategorien der intelligiblen Walt (Nebel); Plotins Leben (Oppermann), E. R. DoDds, I86; $A$ History of Greece (Robinson), M. CARY, I87; Jephthah (Christopherson), E. HARRISON, 189; A Greek: English Lexicon, Part IV. (Liddell and Scott), E. Harrison, I89; Hannibal als Politiker (Groag), G. H. Stevenson, I9o; Cicero: Do Re Publica, De Legibus (Keyes), G. B. A. FLETCHRR, 19I ; Cicero : The Letters to His Friends, Vols. I., II. (Williams). W. T. VeseY, rgI ; Ovide, Héroïdes (Bornecque et Prévost), 194; The Roman Fort at Old Kilpatrick (Miller), $\mathfrak{D}$. Atxinson, r97; Some class-books, W. E. P. Pantin

Short Notices

Books Received.

No. 6.

Reviews (continued) :

Or BAZI ET⿱亠八厶 (Eisler). A. D. Nock, 224: Etat actuel des études sur lo rythme de la prose latime (Novotný), H. D. BrondeEAD, 226 ; $L$. Annaei Senecae Dialogorum liber VI. (Favez); Dvt Konsolace Senckovy (Ryba), G. B. A. FLETChER, 227 : Seneca : Moral Essays. I. (Basore), G. B. A. Fletcher, 229; The Romanization of Africa Proconsularis (Broughton), J. G. C. ANDERSON, $23^{\circ}$; Some annuals, E. HARRISON, 231; $A$ Book of Latin Prose and Latin Verse (Wright), W. E. P. Pantin, 232 ; Some classbooks, H. LISTrR . • . . . . 232

Short Reviews . . . . . . . . 235

Summaries of Periodicals . . . . . . 245

Books Received . . . . . . . 246

Index . $\quad . \quad+\quad \cdot \quad \cdot \quad \cdot \quad 47$ 